\title{
Chemistry Teachers' Perspectives on Virtual STEM Laboratories as Learning Media
}

\author{
Nurul Fitri Rahmadani ${ }^{1}$, Sri Retno Dwi Ariani $^{2}$, Sri Mulyani ${ }^{2}$, Nurma Yunita \\ Indriyanti ${ }^{2, *}$
}

\author{
${ }^{1}$ Master of Chemistry Education, Faculty of Teacher Training and Education, Universitas Sebelas Maret, \\ Indonesia \\ ${ }^{2}$ Department of Chemsitry Education, Faculty of Teacher Training and Education, Universitas Sebelas Maret, \\ Indonesia \\ *Corresponding author. Email: nurma.indriyanti@staff.uns.ac.id
}

\begin{abstract}
The virtual STEM laboratory is a STEM-based learning media alternative as practicum media because the laboratory has some limitations. This study aims to determine the perspective of chemistry teachers on the existence and use of virtual STEM laboratories. The method used is descriptive qualitative research, where the teacher's perspective is obtained from filling out questionnaires and interviews that have been conducted with eleven chemistry teachers with different teaching periods. The results showed most of the teachers delivered material based on the syllabus and delivered practicum-based material in a combination. Eight out of eleven teachers stated that a chemistry laboratory was available in their school, but chemistry practicum was only carried out on materials where the tools and materials were readily available. All teachers agreed with a virtual STEM laboratory because it can complement unsufficient facilities. The teacher used virtual STEM laboratory to deliver materials in the topics of atomic structure, reaction rate, stoichiometry, acid-base, chemical reactions, redox, chemical equilibrium, voltaic cells, electrolytes and non-electrolytes solution, thermochemistry, electrolysis, and the colligative properties of solutions. This study concludes that all teachers agree with the development of a virtual STEM laboratory and are enthusiastic about using it to support chemistry learning.
\end{abstract}

Keywords: Teachers' perspectives, Virtual STEM laboratory, Chemistry learning

\section{INTRODUCTION}

The laboratory is a means of supporting learning activities in schools, one of which is chemistry learning. Understanding chemistry depends on understanding abstract things, so it is not easy to connect various chemical concepts [1]. Abstract material can be studied by conducting experiments or practicum in the laboratory because it is proven that learning in the laboratory positively impacts students' chemistry learning outcomes [2]. Practicum activities in the laboratory make a positive contribution to achieving learning goals [3]. The laboratory can be useful for learning when the teacher's ability [4], facilities and infrastructure, and laboratory management are included in the excellent category [5]. Several obstacles cause chemistry lab work in schools is not always done. Facilities and time constraints are the obstacles that many schools experience when doing chemistry lab work [6], [7]. The rapid development of technology, especially in education, can help overcome the obstacles experienced. Chemical materials that are abstract and difficult to do practicum can take advantage of technology to support the material's delivery. Technology can help overcome obstacles in carrying out practicum in real laboratories.

One technology that can be used to overcome obstacles in a real laboratory is using a virtual laboratory. The virtual laboratory is one of the media innovations that can support and enhance chemistry learning [8]-[10]. The virtual laboratory is considered an alternative pedagogical approach to address the limitations in real laboratories. Virtual laboratories are proven to support practicum-based chemistry learning [11]-[13]. Virtual laboratories help improve students' 
understanding, skills, and learning independence towards chemistry learning [14], [15].

As the demands of the 21 st century, STEM skills can be obtained from practicum activities, which are among the applications of chemical literacy. STEM education can lead students to have multidimensional abilities because it is seen as skills, abilities, factual knowledge, procedures, concepts, and metacognitive abilities for further learning [16] so that STEM is considered essential to be introduced to the world of education. STEM can be integrated via a virtual laboratory. Virtual STEM laboratories improve students' understanding of chemistry and improve STEM literacy [17], [18]. Unfortunately, STEM integrated virtual laboratories are still rare; this is in line with the lack of understanding regarding STEM. To prepare STEM skills obtained from practicum activities, research that focuses on the teacher's perspective is needed. This study is intended to describe the chemistry teacher's perspective on the virtual STEM laboratory. This research is expected to provide an overview of a virtual STEM laboratory is needed to be developed.

\section{METHOD}

This research is a qualitative descriptive study that aims to see the chemistry teacher's perspective on virtual STEM. The teacher's perspective is obtained from the results of filling out the questionnaire and interviewing the teacher. Eleven teachers filled out a questionnaire on the google form, and four teachers were selected to conduct interviews in the existence of a virtual STEM laboratory. Eleven teachers were research subjects from different schools with varying teaching periods.

A questionnaire consists of twelve open-ended questions related to chemistry learning, chemistry laboratory conditions, virtual STEM laboratory, and teacher expectations. The question items in the questionnaire were then developed to become material in preparing the interview sheets. Interview sheet with in-depth interview protocol. There are several items with a different number in each category-the teacher's categories related to chemistry learning, schools, virtual STEM laboratories, and teacher expectations. In addition to these four categories, there is one question regarding other matters related to chemistry learning that the teacher wants to convey to researchers. The data from the interview results were then analyzed and coded to be interpreted using the rubric that had been made. The data obtained is divided into two, namely appropriate/ inappropriate and exposure to a summary of each teacher's answers.

\section{RESULTS AND DISCUSSION}

The teacher's perspective is obtained from the results of a survey and in-depth interviews. The survey and interview sheets were adapted from several sources [19]-[21], which have been adapted to the researchers' needs. The question items are categorized into four categories: chemistry learning, school facilities, virtual STEM laboratories, and teacher expectations. The results of the questionnaire and interview are summarized in table 1.

\subsection{Chemistry Learning}

Based on Table 1, in the category related to the chemistry learning point a, most of the teachers have delivered the material following the learning objectives and the applicable syllabus, but there are still two teachers who are not suitable. Point $b$ in this category, some teachers do a combination in delivering material that requires experimentation to support student understanding. From the questionnaire results, some teachers chose to play experimental videos related to the material being taught; some teachers demonstrated and invited students to do simple experiments. Based on the results of in-depth interviews with four teachers, they conveyed theories related to the material before carrying out a simple experiment or playing an experimental video. The material being experimented on was material that did not require various tools and materials. Activities in the laboratory are proven to positively impact student learning outcomes because abstract material can be experimented with [2].

\subsection{Chemical Laboratory Conditions at School}

The next category relates to laboratory conditions in schools. Eight teachers said that the school where they taught had a chemistry laboratory available, but in schools G4, G8, and G9 there were no chemistry laboratories. Three teachers whose schools do not yet have a laboratory conducted several simple experiments in the classroom using available tools and materials in the surrounding environment. Not all practicum-based materials were carried out experiments. The four teachers only conducted experiments on the material with experiments using simple tools and materials. Like the research conducted by Nuswowati, of the 25 practicum programs in SMA, with 22 programs analyzed, only eight programs were appropriately completed. The rest were never completed [6]. 
Table 1. Analysis the chemistry teacher's perspective

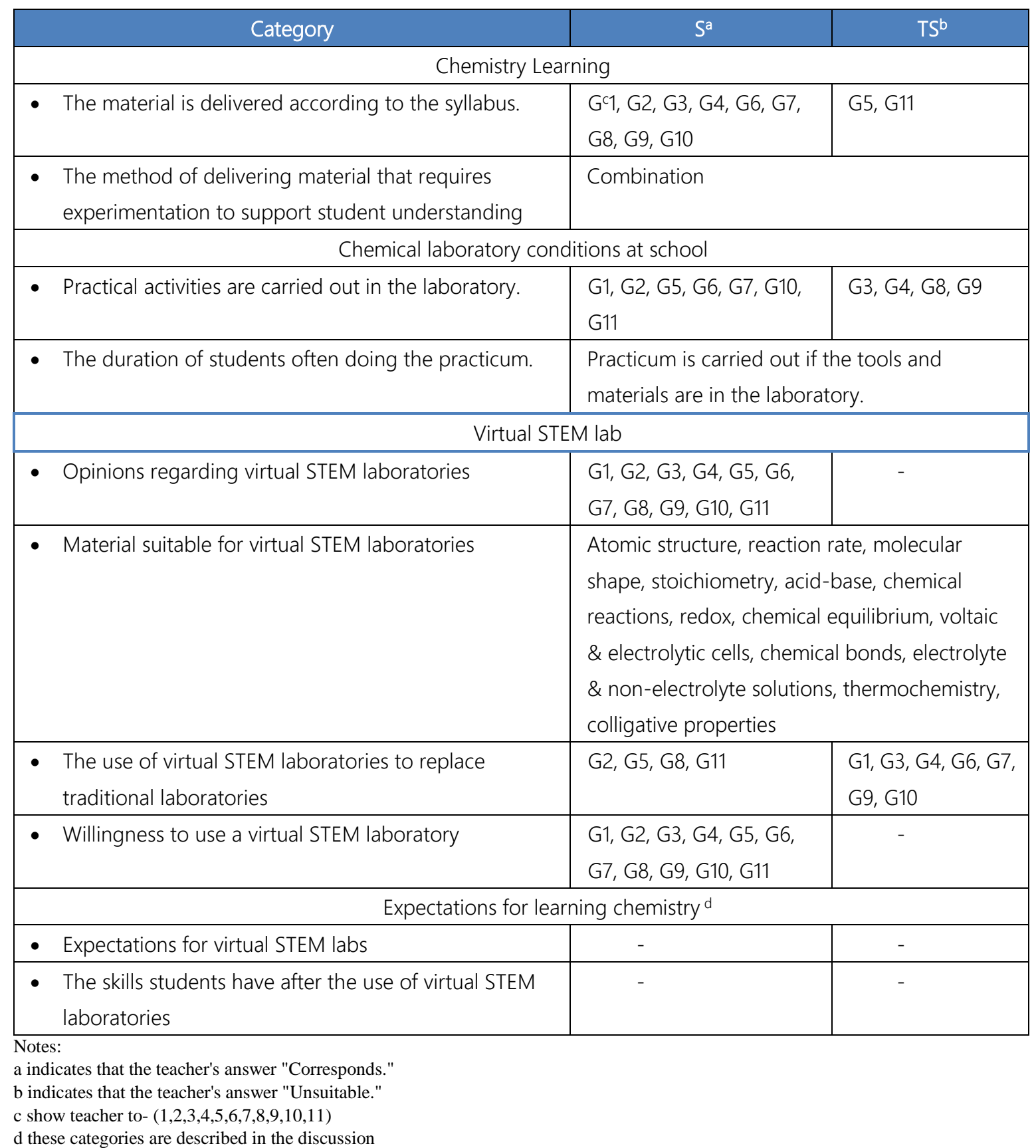

The next point is related to the duration of frequent students doing the trial. Most of the teachers said they rarely did practicum, but $\mathrm{G} 7$ said that once a month, they always did experiments in the laboratory, and G10 often did practicum because it was adjusted to the essential competencies of each material. The obstacles faced by many teachers during practicum activities are the availability of tools and materials in the laboratory. Besides, the time duration is considered insufficient, and there are no laboratory assistants in several schools. G6 also said that sometimes the schedule that coincided with other teachers also became an obstacle to doing a practicum in the chemistry laboratory. Previous research that facilities and time constraints are obstacles to chemistry practicum in schools [6], [7].

In interviews with four teachers, they were asked about computer laboratories to support chemistry learning. They said that so far, they had never used a computer laboratory to support learning. Computer labs are only used for chemistry exams. However, in 
the four schools, Wi-Fi is available, which can support student learning.

\subsection{Virtual STEM Lab}

From the results of the interviews, three teachers have attended training that discussed the STEM approach. STEM is an integrated approach to four main subjects (science, technology, engineering, and mathematics) to emphasize students' ability to solve problems creatively and innovatively [22]. Based on the Table. 1, all the teachers expressed positive things regarding the virtual STEM laboratory. Most of the teachers said that a virtual STEM laboratory could help with learning activities, especially for materials that required practicum to support understanding and there was no chemistry laboratory in schools. In contrast to this, G10 states that the virtual STEM laboratory is a renewal that can develop teachers' and students' abilities. Virtual laboratories can improve learning outcomes, learning independence, and students' ability to understand concepts and their implementation in life [15].

Next, questions are asked regarding which material is suitable for a virtual STEM laboratory. Nine teachers gave their opinions regarding the appropriate material as listed in Table 1, while the other two teachers said it would be better if they were in the virtual STEM laboratory. Understanding chemistry cannot be separated from understanding things that are abstract [1]. Next is the teacher's opinion about using virtual STEM laboratories as a substitute for real laboratories. Based on Table 1, seven teachers stated that they disagreed that virtual STEM laboratories should replace real laboratories. For them, a virtual STEM laboratory is a support and an alternative to a real laboratory. The virtual laboratory is an alternative for teachers as a practicum medium if the real laboratory cannot be used for various reasons [13], [23]. So, experiments in real laboratories must still be done to support learning, especially for material that is not enough to just use virtual laboratories in teaching [19]. While experiments with virtual laboratories can help students visualize the phenomena that are the basis of an experiment, so that students are helped when doing real experiments [24], and are one of the media that can be used to support learning [8], [9], [12]. The next point is related to the willingness of teachers to use virtual STEM laboratories to teach practicum-based chemistry learning. Judging from Table 1, all teachers are willing to use the virtual STEM laboratory. STEM can be presented in a virtual laboratory so that students can build skills acquired through STEM learning [18]. A virtual STEM laboratory can assist in achieving learning goals in a more time-efficient manner. This is following the practicum role in learning chemistry, which makes it easier to achieve competency in knowledge, skills, and shape student character [25].

\subsection{Expectations for Learning Chemistry}

The teacher expressed some hopes after using the virtual STEM laboratory. Practicum with a virtual STEM laboratory is expected to be able to make students more familiar with chemical concepts so that learning outcomes and student creativity can increase. The virtual STEM laboratory makes students feel more actively involved during the experiment because they can control the experiments themselves [23], [26]. Students must be actively involved in STEM learning [27]. The teacher also hopes that students have more thinking and creativity skills than practicum with ordinary laboratories. Student creativity needs to be continuously trained so that students' high-level thinking skills increase [28]. Virtual STEM laboratories can also improve students' STEM literacy [17], where the skills obtained from STEM literacy can help solve problems in real life [29]. Creative students can increase their knowledge of learning and its relationship in life [30].

The eleven teachers who were the subjects in this study did not provide expectations or input that focused on STEM. They convey more hope for virtual labs. However, the expectations expressed by some of these teachers implicitly alluded to the STEM learning outcomes. The teacher hopes that students have the critical thinking, creative, literacy skills, and can take advantage of technology more than practicum with real laboratories. Students' 4C skills can be improved through STEM-PjBL learning [31]. The teachers have understood and understood the outcome of STEM learning, so they showed a positive perspective towards the virtual STEM laboratory and were very enthusiastic about the development of the virtual STEM laboratory.

The virtual STEM laboratory is expected by teachers to be able to help the learning process. The teacher shares some of the advantages of the virtual STEM laboratory in chemistry learning. With the virtual STEM laboratory, students still get real experiences like in traditional labs [9], [32], which can improve students' science process skills [32], support the chemistry learning process [9]. In addition, with a virtual STEM laboratory, students can gain a better understanding of theoretical topics [33] and can implement them in life. It is hoped that the virtual STEM laboratory that will be developed is easily 
accessible and applied in chemistry learning. Teachers really hope that the virtual STEM laboratory can help with problems related to real laboratories in schools so far. However, in addition to strengths, virtual laboratories also have weaknesses, namely, students' skills in using laboratory equipment and tools, measuring, and collaborating with friends cannot be obtained from a virtual STEM laboratory [34].

In addition to the four categories previously discussed, in the interviews conducted with four teachers, they also conveyed several things related to chemistry learning. G1 said always to motivate students to be interested in learning chemistry with pleasure. Students are invited to try new things such as practicums with virtual STEM laboratories so that it is more fun because they seem to like playing games on their cellphones or laptops. Student motivation can be obtained from activities that involve students in project-based learning [35]. G2 said that all of the materials would not be conveyed if practicum-based materials were carried out by practicum all because each material needed several repetitions to understand the students. It is felt that a virtual STEM laboratory will be very helpful in delivering chemistry material, understanding students, in a more efficient time so that all material can be conveyed. According to G3, chemistry learning must be made as attractive as possible, teachers must be creative so that learning is not monotonous and students are always happy and comfortable when learning. The virtual STEM laboratory will be very attractive to students. After all, it is considered contemporary because it can be done on students' laptops or cellphones. This is supported by the results of research which states that chemistry teachers must use computer simulations in learning so that student performance and motivation in learning chemistry increases [36]. G4 said that every chemistry lesson must have something different so that students don't get bored but still the material is conveyed and students understand, because the way the teacher delivers the material can affect student understanding [37].

\section{CONCLUSION}

Nine out of eleven teachers stated that the material presented in chemistry learning was following the syllabus. Practical-based material is delivered in a combination way, namely the delivery of theory before demonstrations, practicum, or experimental video screenings are carried out. Meanwhile, regarding the laboratory condition in the school, eight teachers said that a chemistry laboratory was available, and three other teachers said there was no chemistry laboratory in the school they taught. Practical activities are only carried out on materials whose tools and materials are easy to obtain and can be done simply. In the category related to virtual STEM laboratories, eleven teachers agreed with a virtual STEM laboratory because they considered virtual STEM laboratories complementary when traditional laboratories were inadequate. According to them, materials suitable for virtual STEM laboratories include atomic structure, reaction rate, molecular shape, stoichiometry, acid-base, chemical reactions, redox, chemical equilibrium, voltaic \& electrolysis cells, chemical bonds, electrolyte \& non-electrolyte solutions, thermochemistry, and colligative nature. Eleven teachers have a positive perspective on the virtual STEM laboratory. They already know about STEM, but do not explain it explicitly when answering their hopes for a virtual STEM laboratory. From the research that has been conducted, it is known that all teachers are enthusiastic and agree to use a virtual STEM laboratory to support chemistry learning.

The results of this study can be used as a basis in developing a virtual STEM laboratory. The use of virtual STEM laboratories in chemical materials or other materials that require practicum can be a consideration for schools in supporting learning during the Covid-19 pandemic.

\section{ACKNOWLEDGMENTS}

The author would like to thank the Ministry of Research and Technology/ National Research and Innovation Agency of the Republic of Indonesia for providing funding for this research through the 2020 Postgraduate Research program.

\section{REFERENCES}

[1] D.F. Treagust, G. Chittleborough, Chemistry: A matter of understanding representations, in: J. Brophy (Ed.), Advances in Research on Teaching: Subject-Specific Instructional Methods and Activites, Emerald Group Publishing, Bingley, West Yorkshire, 2015, pp. 239-267. DOI: http://dx.doi.org/10.1016/S14793687(01)80029-8

[2] M. Penn, U. Ramnarain, A Comparative Analysis of Virtual and Traditional Laboratory Chemistry Learning, Perspective in Education 37(2) (2019) 80-97. DOI: http://dx.doi.org/10.18820/2519593X/pie.v37i2. $\underline{6}$ 
[3] H. Koller, M. Olufsen, M. Stojanovska, V. Petrusevski, Practical work in chemistry, its goals and effects, in: I. Maciejowska, B. Byers (Eds.), A Guidebook of Good Practice for The Preservice Training of Chemistry Teachers, Jagiellonian University, Krakow, 2015, pp. 87106.

[4] A. Hofstein, The Laboratory in Chemistry Education: Thirty Years of Experience With Developments, Implementation, and Research, Chemistry Education Research and Practice 5(3) (2004) 247-264. DOI: https://doi.org/10.1039/B4RP90027H

[5] S. Rahmiyati, Keefektifan Pemanfaatan Laboratorium di Madrasah Aliyah Yogyakarta, Jurnal Penelitian dan Evaluasi Pendidikan 11(1) (2008) 88-100. DOI: https://doi.org/10.21831/pep.v11i1.1420

[6] M. Nuswowati, W. Sumarni, M. Taufiq, Analysis of quantity and quality the implementation of high school chemical practicum in Semarang city, in: Journal of Physics: Conference Series, vol.1567, IOP Publishing, Bristol, 2020, pp. 1-6. DOI: $\quad$ https://doi.org/10.1088/1742$\underline{6596 / 1567 / 4 / 042011}$

[7] D. Rahman, Adlim, Mustanir, Analisis Kendala dan Alternatif Solusi Terhadap Pelaksanaan Praktikum Kimia pada SLTA Negeri Kabupaten Aceh Besar, Jurnal Pendidkan Sains Indonesia 3(2) (2015) 1-13.

[8] F.S. Arista, H. Kuswanto, Virtual Physics Laboratory Application Based on the Android Smartphone to Improve Learning Independence and Conceptual Understanding, International Journal of Instruction 11(1) (2018) 1-16.DOI: https://doi.org/10.12973/iji.2018.1111a

[9] Z. Tatli, A. Ayas, Effect of A Virtual Chemistry Laboratory on Students' Achievement Technologies for The Seamless Integration of Formal and Informal Learning, Journal of Educational Technology and Society 16(1) (2013) 159-170. DOI: https://doi.org/10.2307/jeductechsoci.16.1.159

[10] M. Muhamad, H.B. Zaman, A. Ahmad, Virtual Laboratory for Learning Biology - A Preliminary Investigation, International Journal of Educational and Pedagogical Sciences 4(11) (2010) 2179-2182.
[11] I. Hawkins, A.J. Phelps, Virtual Laboratory Vs. Traditional Laboratory: Which Is More Effective for Teaching Electrochemistry?, Chemistry Education Research and Practice 14(4) (2013) 516-523.

DOI: https://doi.org/10.1039/c3rp00070b

[12] A. Hidayat, V.G. Utomo, Virtual Laboratory Implementation to Support High School Learning, International Journal of Computer Applications 120(16) (2015) 14-18. DOI: https://doi.org/10.5120/21310-4283

[13] K. Winkelmann, M. Scott, D. Wong, A Study of High School Students' Performance of A Chemistry Experiment within The Virtual World of Second Life, Journal of Chemical Education 91(9) (2014) 1432-1438. DOI: https://doi.org/10.1021/ed500009e

[14] N. Hikmah, N. Saridewi, S. Agung, Penerapan Laboratorium Virtual untuk Meningkatkan Pemahaman Konsep Siswa, EduChemia: Jurnal Kimia dan Pendidikan 2(2) (2017) 186-195. DOI:

https://doi.org/10.30870/educhemia.v2i2.1608

[15] Nurazizah, I.R. Suwarma, A. Jauhari, I. Kaniawati, Implementasi pembelajaran STEM: Kajian terhadap pencapaian hasil belajar siswa, in: Prosiding Seminar Nasional Fisika (SINAFI), vol.1, Universitas Pendidikan Indonesia, Bandung, 2018, pp. 126-130.

[16] A. Zollman, Learning for STEM Literacy: STEM Literacy for Learning, School Science and Mathematics 112(1) (2012) 12-19. DOI: https://doi.org/10.1111/j.19498594.2012.00101.x

[17] P. Trúchly, M. Medvecký, P. Podhradský, N. El Mawas, STEM Education Supported by Virtual Laboratory Incorporated in Self-Directed Learning Process, Journal of Electrical Engineering 70(4) (2019) 332-344. DOI: https://doi.org/10.2478/jee-2019-0065

[18] I. Ismail, A. Permanasari, W. Setiawan, STEM Virtual Lab: An Alternative Practical Media to Enhance Student's Scientific Literacy, Jurnal Pendidiakn IPA Indonesia 5(2) (2016) 239-246. DOI: https://doi.org/10.15294/jpii.v5i2.5492

[19] Elsunni, H. Abdelwahed, Stakeholders Perspective on The Efficiency of The Virtual Laboratory in The Development of Students Scientific Research Skills in Science, American 
International Journal of Social Science 3(2) (2014) 166-171.

[20] O.F. Nugroho, A. Permanasari, H. Firman, The Movement of STEM Education in Indonesia: Science Teachers' Perspectives, Jurnal Pendidikan IPA Indonesia 8(3) (2019) 417-425. DOI: https://doi.org/10.15294/jpii.v8i3.19252

[21] F. Solikhin, J. Ikhsan, K.H. Sugiyarto, A need analysis in developing virtual laboratory according to the chemistry teachers, in: Journal of Physics: Conference Series, vol. 1156, IOP Publishing, Bristol, 2019, pp.1-6. DOI: https://doi.org/10.1088/1742$\underline{6596 / 1156 / 1 / 012020}$

[22] A. Roberts, A Justification for STEM Education, Technology and Engineering Teacher 72(8) (2012) 1-5.

[23] J.C. Domínguez, R.Miranda, E.J. González, M. Oliet, M.V. Alonso, A Virtual Lab as A Complement to Traditional Hands-On Labs: Characterization of An Alkaline Electrolyzer for Hydrogen Production, Educatio for Chemical Engineers 23(1) (2018) 7-17. DOI: https://doi.org/10.1016/j.ece.2018.03.002

[24] M.G. Rasteiro, L. Ferreira, J. Teixeira, et al., LABVIRTUAL-A Virtual Platform to Teach Chemical Processes, Education for Chemical Engineers 4(1) (2009) 9-19. DOI: https://doi.org/10.1016/j.ece.2009.02.001

[25] D. Nuha, H. Haryono, B. Mulyani, Kontribusi Laboratorium Terhadap Pembelajaran Kimia SMA, Jurnal Pendidikan Kimia 4(1) (2015) 8288.

[26] S. Chen, W.H. Chang, C.H. Lai, C.Y. Tsai, A Comparison of Students' Approaches To Inquiry, Conceptual Learning, and Attitudes in Simulation-Based and Microcomputer-Based Laboratories, Science Education 98(5) (2014) 905-935.

DOI: https://doi.org/10.1002/sce.21126

[27] J.A. Ejiwale, Barriers to Successful Implementation of STEM Education, Journal of Education and Learning 7(2) (2013) 63-74. DOI: http://dx.doi.org/10.11591/edulearn.v7i2.220

[28] S.W. Utomo, M. Ubaidillah, S. Joyoatmojo, S. Yutmini, N. Suryani, Improving Students' Creativity in Video Making by Problem Based Learning Model, International Journal of
Educational Research Review 4(3) (2019) 481488. DOI: https://doi.org/10.24331/ijere.573956

[29] T. Tati, H. Firman, R. Riandi, The effect of stem learning through the project of designing boat model toward student STEM literacy, in: Journal of Physics: Conference Series, vol. 895, IOP Publishing, Bristol, 2017, pp. 1-8. DOI: https://doi.org/10.1088/1742-6596/895/1/012157

[30] D.S. Bolden, T.V. Harries, DP. Newton, PreService Primary Teachers' Conceptions of Creativity in Mathematics, Educational Studies in Mathematics 73(2) (2010). 143-157. DOI: https://doi.org/10.1007/s10649-009-9207-Z

[31] D. Triana, Y.U. Anggraito, S. Ridlo, Effectiveness of Environmental Change Learning Tools Based on STEM-PjBL Towards 4C Skills of Students, Journal of Innovative Science Education 9(2) (2020) 181-187. DOI: https://doi.org/10.15294/JISE.V8I3.34048

[32] F.D. Syahfitri, B. Manurung, M. Sudibyo, The Development of Problem Based Virtual Laboratory Media to Improve Science Process Skills of Students in Biology, International Journal of Research and Review 6(6) (2019) 64 74.

[33] V. Kumar, S. Kumari, A Study Virtual Laboratory: Objective, Comparison and Benefits, International Journal of Innovations and Advancement in Computer Science 5(6) (2016) 71-73.

[34] Z. Tatli, A. Ayas, Virtual laboratory applications in chemistry education, in: Procedia- Social and Behavioral Sciences, vol. 9, Elsevier, Amsterdam, 2010, pp. 938-942. DOI: https://doi.org/10.1016/j.sbspro.2010.12.263

[35] Y.S. Naor, M. Kesner, Y. Shwartz, Enhancing Students' Motivation to Learn Chemistry, Sisyphyus Journal of Education 2(2) (2014) 100123. DOI: https://doi.org/10.25749/sis.4068

[36] I.A. Gambari, B.E. Gbodi, E.U. Olakanmi, E.N. Abalaka, Promoting Intrinsic and Extrinsic Motivation among Chemistry Students Using Computer-assisted Instruction, Contemporary Educational Technology 7(1) (2016) 25-46. DOI:

https://doi.org/10.31901/24566322.2016/12.02.0 $\underline{7}$

[37] C. Wu, J. Foos, Making Chemistry Fun to Learn, Literacy Information and Computer Education Journal 1(1) (2010) 1-12. 